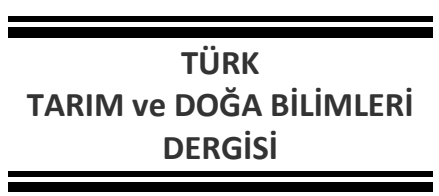

TÜRK

DERGISI

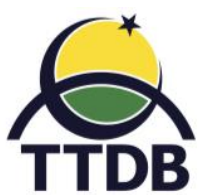

www.dergipark.gov.tr/turkjans

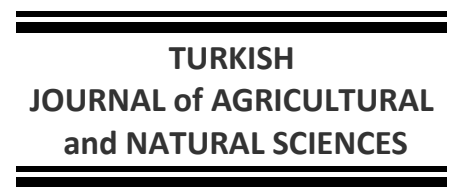

Araştırma Makalesi

\title{
Siirt İli Merkez İlçede Kırmızı Et Tüketim Alışkanlıkları ve Tüketimi Etkileyen Faktörler
}

\author{
Mustafa KiBAR $^{1 *}$, Nazire MiKAiL'2, Ayhan YILMAZ ${ }^{2}$ \\ ${ }^{1}$ Selçuk Üniversitesi Ziraat Fakültesi Zootekni Bölümü, Konya, Türkiye \\ ${ }^{2}$ Siirt Üniversitesi Ziraat Fakültesi Zootekni Bölümü, Siirt, Türkiye \\ *Sorumlu yazar: mustafakibar@siirt.edu.tr
}

Geliş Tarihi: 25.02 .2019

Düzeltme Geliş Tarihi: 29.07.2019

Kabul Tarihi: 23.08.2019

\section{Özet}

Kırmızı et tüketimi insanların sağlıklı beslenmesinde ve ülkelerin gelişmişlik düzeyinin belirlenmesinde önemli bir faktördür. Bu çalışma Siirt ili Merkez ilçede kırmızı et tüketim alışkanlı̆̆ını ve tüketimi etkileyen faktörleri incelemek amacıyla yapılmıştır. Veriler tesadüfi örnekleme metoduyla belirlenen 161 kişi ile yüzyüze anket yapılarak elde edilmiştir. Deneklerin yaklaşık olarak yarısı kadınlardan oluşmakta ve çoğunluğu Siirt ilinde sadece ikamet ettiklerini belirtmiştir. Araştırmaya katılanların çoğunluğu lise-lisans derecesine sahip, evli ve orta yaşlı insanlardan oluşmaktadır. Katılımcılar genellikle koyun etini, orta fiyatlı etleri ve alım yeri olarak da kasabı tercih etmektedirler. Katılımcıların kırmızı eti tercih etmesinde alışkanlık başta olmak üzere lezzetli ve sağlıklı olması gibi faktörler de etkili olmuştur. Tüketiciler kırmıı et satın alırken alım yerinin hijyenik olmasına ve ürünlerin etiketli olmasına daha çok dikkat etmişlerdir. Tüketicilerin et tüketim miktarları üzerine ailedeki birey sayısı, aylık ortalama gelir ve aylık ortalama gıda harcaması etkili olmuştur. Sonuç olarak Siirt ilinde daha çok koyun etinin tüketildiği ve bu durumun bölgede küçükbaş hayvancılığın yaygın olmasından ve dolayısıyla alışkanlıktan kaynaklandığı düşünülmektedir.

Anahtar kelimeler: Kırmızı et, tüketim alışkanlıkları, Siirt ili.

\section{Red Meat Consumption Habits and Affecting Factors in Central District of Siirt Province}

\begin{abstract}
Red meat consumption is an important factor in healthy eating of people and determining the level of development of countries. This study was conducted to investigate the red meat consumption habits and the factors affecting red meat consumption in Siirt City Center. Data were obtained by surveying face to face from 161 people which are determined with random sampling method. Approximately half of the participants consisted of women and the majority stated that they lived only in Siirt province. The majority of the participants were married and middle-aged people with a high-school degree. Participants generally prefer sheep meat, medium-priced meats and butchers as their place of purchase. Factors such as being delicious and healthy, especially habit, were effective in the participants' preference for red meat. Consumers have paid more attention to the hygienic place of purchase and labeling of products when buying red meat. The number of individuals in the family, average monthly income and average monthly food expenditure were effective on the meat consumption of consumers. As a result, sheep meat is consumed more in Siirt province and this situation is thought to be due to the widespread sheep and goat breeding in the region.
\end{abstract}

Key words: Red meat, consumption, habit, Siirt province. 


\section{Giriş}

Sağlıklı ve dengeli beslenmede kişi başına günlük alınması gereken protein miktarının \%4050'sinin hayvansal kaynaklı olmasına ihtiyaç duyulmaktadır. Hayvansal kaynaklı proteinler içerisinde et, insanlık tarihi boyunca önemli bir gıda maddesi olmuştur (Arıtaşı, 2009). Et, insanların büyümesi ve gelişmesi için ihtiyaç duyulan tüm aminoasitleri bünyesinde barındıran önemli bir besin maddesidir (Göğüş, 1986). Ülkelerin gelişmişlik düzeyi ve yaşam kalitesi standartlarının belirlenmesinde de et veya hayvansal kaynaklı proteinlerin tüketim düzeyi önemli ölçütlerden biridir (Yücel, 2001). Öte yandan insanların kültür düzeyi, geliri ve sosyal yaşantı özellikleri et tüketim alışkanlıklarını etkileyen önemli faktörlerdir. Dolayısıyla günümüzde sosyo-ekonomik düzeyi yüksek olan ülkelerde et tüketim oranlarının da yüksek olduğu söylenebilir (Kan ve Direk, 2004; Arısoy ve Bayramoğlu, 2014). Türkiye'de 2017 yılı itibariyle büyükbaş ve küçükbaş hayvan varlığı sırasıyla 16105025 baş ve 44312308 baş olup, kişi başına yıllık kırmızı et tüketimi 2017 yılında 13.92 kg'dır (TÜiK, 2018a). Özellikle kişi başına yıllık et tüketimi değerlendirildiğinde gelişmiş ülkelerin çok gerisinde kaldığımız açıkça görülmektedir. Türkiye'de toplam yıllık et üretimi 1118695 ton olup mevcut üretim, nüfusla birlikte değerlendirildiğinde, bunun yeterli olmadığı açıktır. Bu durum aynı zamanda et fiyatlarına da yansımaktadır (Tömek, 1989; Onurlubaş ve ark., 2015). Türkiye'de et tüketim alışkanlığı ile ilgili çeşitli illerimizde araştırmalar yapılmış ve kırmızı et tüketim eğilimleri ortaya konulmuştur (Karakuş ve ark., 2008; Yaylak ve ark., 2010; Şeker ve ark., 2011; Akçay ve Vatansever, 2013). Rimal (2002) Amerika'da yaptığı çalışmasında tüketicilerin kırmızı et tercihlerinin coğrafik konumdan, ırksal geçmişlerinden, aile durumundan ve gelirden etkilendiğini bildirmiştir. Aynı araştırmacı kadınlar ile erkekler arasında et tüketimi arasında önemli bir ilişki olmadığını belirtmekle birlikte, kadınların kırmızı et olmayan yemekleri daha çok tercih ettiklerini bildirmiştir. Fonti-Furnols ve Guerrero 2014 çalışmasında tüketicilerin et ve et ürünleri tercihlerinde etkili olan faktörleri (inanç, tavır, beklenti, görüntü, tat, özellik, koku, etiket vb.) genel olarak incelemiştir. Araştırmacı sonuç olarak, etiket, bilgi ve sunulan farklı seçeneklerin tüketicinin tercihi üzerinde etkili olduğunu bildirmişlerdir.

Siirt ilinde 2017 yılı itibarıyla 324.394 kişi bulunmaktadır (TÜiK, 2018b). Siirt ilinde 2017 yılı itibarıyla 28147 baş sığır ve 1.123 .116 baş koyun ve keçi bulunmaktadır. Siirt ilinin doğu ve kuzey bölgelerinde kış ayları daha soğuk ve yağışlı geçerken, güney ve güney batı bölgelerinde ise kış aylarının daha ılıman geçerken ilde yaz aylarının ise sıcak ve kurak bir iklime sahip olduğu belirtilmektedir. Siirt ilinde en yüksek sıcaklıklar Ağustos ve Eylül aylarında, en düşük sıcaklıklar da Ocak ve Şubat aylarında yaşanmaktadır. Nem oranı bakımından ise Aralık ve Ocak ayları \%70 nem oranı ile en üst sırada yer alırken, yıllık ortalama nem oranı \%51'dir (Turan ve ark., 2015). Bu araştırma, Siirt il Merkezinde kırmızı et tüketim alışkanlığını ve etkileyen faktörleri belirlemek amacıyla yapılmıştır.

\section{Materyal ve Yöntem}

Siirt ili Türkiye'nin Güneydoğu Anadolu Bölgesinde yer almakta, Tillo, Baykan, Eruh, Kurtalan, Merkez, Pervari ve Şirvan olmak üzere 7 ilçeden oluşmaktadır (Şekil 1). Özellikle küçükbaş hayvan varlığı bakımından değerlendirildiğinde Siirt ilinde bu hayvancllık kolunun önemli bir hayvancllık faaliyeti olduğu açık bir şekilde ortaya çıkmaktadır. Bu üretim kolu içinde uzun yıllardır devam ettirilen göçer veya yarı göçer koyunculuk faaliyetleri de önemli bir ayırt edicilik özelliği taşır.

Çalışmada Siirt il Merkezinde kırmızı et tüketim alışkanlığını belirlemek amacıyla Oran için en uygun örnek hacminin belirlenmesi formülü (Newbold, 1995) ile seçilen 161 katılımcıyla birebir görüşülerek anket yapılmıştır:

$$
n=\frac{z^{2} p q}{d^{2}}
$$

(Eş. 1)'de $n$ - gerekli örnek büyüklüğünü, $p-$ ana kitle içinde istenen durumun oranını $(p=0.5), q-$ ana kitle içinde istenmeyen durumun oranını $(q=0.5)$, $z$-istenen güven derecesini yansıtan standart normal dağılım tablosundaki değeri $\left(z_{0.1}=1.65\right)$ ve $d$ - orandan izin verilen en büyük hata miktarını $(d=\% 6)$ ifade etmektedir. Anketler 2017 yılında tüketiciler ile yüz yüze yapılmıştır. Ankette katılımcıların cinsiyeti, yaşı, memleketi, hanedeki birey sayısı, medeni hali, eğitim durumu gibi demografik özelliklerine ilave olarak et tüketim alışkanlıklarını belirlemeye yönelik soruları da kapsayacak şekilde toplam 18 soru maddesine yer verilmiştir. Bazı özellikler arasında bağımsızlı̆̆ın olup olmamasını kontrol etmek için $\chi^{2}$ bağımsızlık testi uygulanmıştır (Eş. 2).

$$
\aleph^{2}=\sum_{i=1}^{r} \sum_{j=1}^{c} \frac{\left(G_{i j}-B_{i j}\right)^{2}}{B_{i j}} \sim \aleph_{(r-1)(c-1), \alpha}^{2}
$$


Burada, $G_{i j}$ - Gözlenen değer, $B_{i j}$ - Beklenen değer, $i=1, \ldots, r$ satır sayısı, $j=1, \ldots, c$ sütun sayısı, $\alpha-$ hata payıdır.
Elde edilen verilerin istatistik analizinde SPSS paket programı kullanılmıştır.

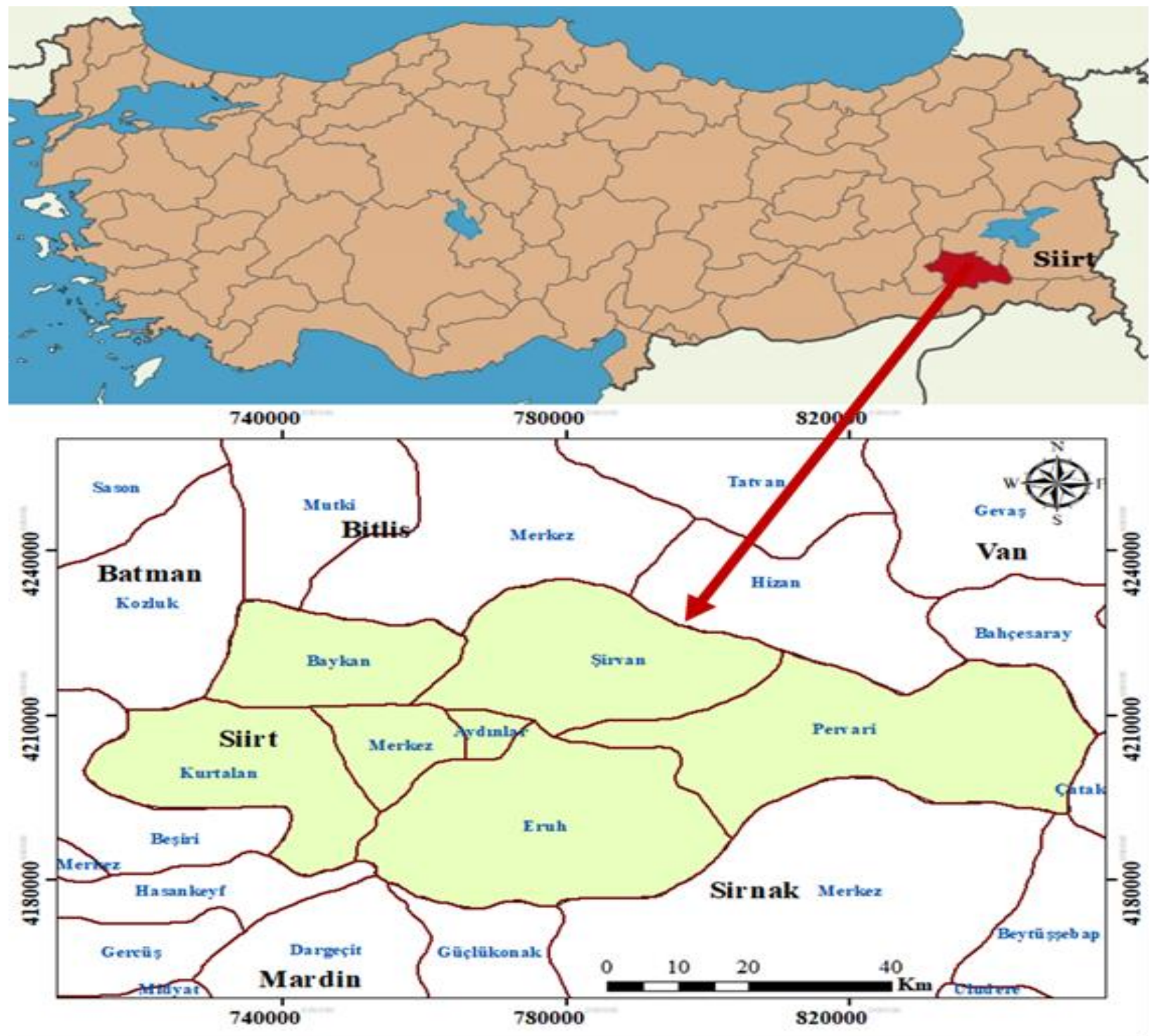

Şekil 1. Araştırmanın yapıldığı bölge.

\section{Bulgular ve Tartışma}

Ankette katılımcıların demografik özelliklerine ilişkin bazı bilgiler Çizelge 1'de verilmiştir. Buna göre ankete katılanların \%52.2'si erkek, \%47.8'i ise kadın katılımcılardan oluşmuştur. Memleket durumu ile ilgili olarak katılımcıların \%60.2'si Siirt nüfusuna kayıtlı olduklarını, \%39.8'i ise sadece Siirt ilinde ikamet ettiklerini ifade etmişlerdir. Araştırmada medeni duruma ilişkin ifadede evli ve bekâr olan katılımcıların oranı sırasıyla \%80.1 ve\%19.9 olarak bulunmuştur. Katılımcılar yaş dağılımlarına göre değerlendirildiğinde ise 25 ve altı yaşta olanların oranı
\%12.4, 26-30 arasında olanların oranı \%24.8, 31-40 arasında olanların oranı \%34.8, 41-50 arasında olanların oranı $\% 14.9,51$ ve üzeri yaşa sahip olanların oranı ise \%13 olarak saptanmıştır. Anket katılımcılarının eğitim durumu bakımından dağılımları \%4.3okuryazar olmayan, \%16.8 ilkokul, \%16.1 ortaokul, \%29.8 lise ve \%32.9 ise üniversite şeklindedir. Katılımcıların ailelerindeki birey sayıları 3'ten az, 3-5 kişi, 5-8 kişi ve 8'den fazla olanların oranları sırasıyla \%17.4, \%39.1, \%35.4 ve \%8.1 olarak tespit edilmiştir. 
Araştırmada Siirt ilinde kırmızı et tüketim alışkanlığına ilişkin sorulardan kırmızı et ve işlenmiş et tüketme durumları, ortalama aylık gelirleri, gıda harcamaları, et tüketim miktarı, eti satın alma şekli, et tüketim biçimine ilişkin alınan cevapların oranı Tablo 2'de verilmiştir. Buna göre katılımcılardan aylık gelirleri 1400 TL'den az, 1400-3000 TL arası ve 3000 TL'den fazla ifadelerine yönelik oranları sırasıyla
\%16.1, \%52.2 ve \%29.8'dir. Katılımcıların \%75.8'i işlenmiş et ürünleri tükettiğini bildirirken, \%24.2'si tüketmediğini ifade etmiştir. Yine, katılımcıların \%99.8'i kırmızı et tükettiğini belirtirken, yalnızca $\% 1.2$ 'si kırmızı et tüketmediğini ifadesini işaretlemiştir. Kırmızı et tüketmeme sebebi olarak vejetaryen ve pahalı olduğu için seçeneklerine katılım oranları sırasıyla \%16.7 ve \%83.3 olmuştur.

Çizelge 1. Anket sonuçlarına ilişkin demografik özellikler

\begin{tabular}{|c|c|c|c|}
\hline \multicolumn{2}{|c|}{ Demografik özellikler } & \multirow{2}{*}{$\frac{\mathbf{n}}{84}$} & \multirow{2}{*}{$\begin{array}{c}\% \\
52.2\end{array}$} \\
\hline Cinciut & Erkek & & \\
\hline cinsiyet & Kadın & 77 & 47.8 \\
\hline \multirow{2}{*}{ Memleket } & Yerli & 97 & 60.2 \\
\hline & Siirt dışı & 64 & 39.8 \\
\hline \multirow{4}{*}{ Medeni hali } & Evli & 129 & 80.1 \\
\hline & Bekâr & 26 & 16.1 \\
\hline & Boşanmış & 1 & 0.6 \\
\hline & Dul & 5 & 3.1 \\
\hline \multirow{5}{*}{ Yaş } & 25 ve altı & 20 & 12.4 \\
\hline & $26-30$ & 40 & 24.8 \\
\hline & $31-40$ & 56 & 34.8 \\
\hline & $41-50$ & 24 & 14.9 \\
\hline & 51 ve üzeri & 21 & 13.0 \\
\hline \multirow{5}{*}{ Eğitim durumu } & Okuryazar değil & 7 & 4.3 \\
\hline & ilkokul & 27 & 16.8 \\
\hline & Ortaokul & 26 & 16.1 \\
\hline & Lise & 48 & 29.8 \\
\hline & Üniversite & 53 & 32.9 \\
\hline \multirow{2}{*}{ Birey sayısı } & $<3$ & 28 & 17.4 \\
\hline & 3-5 kişi & 63 & 39.1 \\
\hline
\end{tabular}

Katılımcıların aylık gıda harcamaları durumuna ilişkin olarak 400 TL'den az, 400-800 TL, 800-1500 TL ve $1500 \mathrm{TL}$ ve üzeri seçeneklerine ilişkin cevapların oranları sırasıyla \%10.6, \%60.2, \%24.2 ve \%5 olarak bulunmuştur. Katılımcıların eti kemiksiz (\%16.1), kıyma (\%7.5), kemikli (\%17.4) ve bunların farklı birleşimleri şeklinde satın aldıkları ve en çok tercih edilen birleşimin kemiksiz-kıyma-kemikli (\%40.4) olduğu görülmüştür. Kırmızı et tüketme nedeni olarak belirtilen lezzetli, besleyici, alışkanlık, sağıklı ve bunların farklı birleşimleri ile en çok lezzetli-besleyici ifadelerine katılım düzeyleri sırasıyla \%20.6, \%5.6, \%3.8, \%7.5 ve \%22.5 olmuştur. Katılımcıların eti tüketim şekline ilişkin olarak \%3.8'ü ızgara, \%11.9'ü haşlama, \%2.5'i fırında, \%2.5'i sebzeli, \%2.5'i yağda kızartma ve \%77.0'ı ise bunların hepsini tükettiklerini ifade etmişlerdir. Araştırmada aylık et tüketim miktarı durumu ise 2 kg'dan az et tüketenlerin oranı \%23.6, 2$5 \mathrm{~kg}$ arasında et tüketenlerin oranı \%49.1, 5-10 kg et tüketenlerin oranları $\% 19.3$ ve $10 \mathrm{~kg}$ dan fazla et tüketenlerin oranları ise \%8.1 olarak saptanmıştır. Deneklerin ilk sırada tercih ettikleri et çeşitleri sırasıyla koyun (\%56.3), keçi (\%21.9) ve dana (\%20.6) şeklindedir. Deneklerin \%43.1'i orta fiyatlı, \%28.8'i ucuz fiyatlı ve \%26.9'u yüksek fiyatlı etleri ilk sırada tercih etmiştir. Tüketicilerin \% 64.4'ü kasabı, \% 18.1'i kasaplı marketi ve \% 16.3'ü kasapsız marketi ilk sırada et alım yeri olarak tercih etmiştir (Kibar ve Mikail, 2018).

Çizelge 2'de katılımcıların eti satın alma yeri tercih kriterlerine ilişkin oranları verilmektedir. Katılımcılardan hijyeni birinci derecede satın alma kriteri olarak alanların oranı \%35.4 iken, ikinci ve üçüncü derecede satın alma kriteri olarak ifade edenlerin oranı ise sırasıyla \%21.7 ve \%28 olmuştur. Etlerin etiketlenmesini satın alma kriteri açısından birinci, ikinci ve üçüncü derecede önemli görenlerin oranları sırasıyla \%26.7, \%17.4, \%12.4'dir. Yine satın alma kriterleri içinde etin tazeliğini birinci, ikinci ve üçüncü derecede önemli bulan katılımcıların oranları 
sırasıyla \%17.4, \%32.3 ve \%20.5 olmuştur. Tüketicilerin hijyen, etin taze ve etiketli olmasının yanında işletmenin yetkililerce denetlenmesini, evine yakın olmasını, kredi kartı kullanma imkanının olmasını, satıcıya güvenmeyi, satıcının tanıdık olmasını ve etin ucuz olmasını da et satın alırken önemli ölçütler olarak görmüşlerdir.

Çizelge 2. Anket sonuçlarına ilişkin kırmızı et tüketim alışkanlıkları

\begin{tabular}{|c|c|c|c|}
\hline Kırmızı et tüketim alışkanlıkları & & $\mathbf{n}$ & $\%$ \\
\hline \multirow{3}{*}{ Aylık gelir (TL) } & 1400'den az & 26 & 16.1 \\
\hline & $1400-3000$ & 84 & 52.2 \\
\hline & 3000'den fazla & 48 & 29.8 \\
\hline \multirow{2}{*}{ İşlenmiş et ürünleri tüketim } & Evet & 122 & 75.8 \\
\hline & Hayır & 39 & 24.2 \\
\hline \multirow{2}{*}{ Kırmızı et tüketmeme nedeni } & Vejetaryen & 1 & 16.7 \\
\hline & Pahalı & 5 & 83.3 \\
\hline \multirow{4}{*}{ Aylık gıda harcaması (TL) } & 400'den az & 17 & 10.6 \\
\hline & $400-800$ & 97 & 60.2 \\
\hline & $800-1500$ & 39 & 24.2 \\
\hline & 1500 'den fazla & 8 & 5.0 \\
\hline \multirow{7}{*}{ Kırmızı et satın alma şekli } & Kemiksiz & 26 & 16.1 \\
\hline & Kıyma & 12 & 7.5 \\
\hline & Kemikli & 28 & 17.4 \\
\hline & Kemiksiz-kıyma & 11 & 6.8 \\
\hline & Kemiksiz-kemikli & 11 & 6.8 \\
\hline & Kıyma-kemikli & 7 & 4.3 \\
\hline & Kemiksiz-kıyma-kemikli & 65 & 40.4 \\
\hline \multirow{10}{*}{ Kırmızı et tercih etme nedeni } & Lezzetli & 33 & 20.6 \\
\hline & Besleyici & 9 & 5.6 \\
\hline & Alışkanlık & 6 & 3.8 \\
\hline & Sağlıklı & 12 & 7.5 \\
\hline & Diğer & 10 & 6.3 \\
\hline & Lezzetli+besleyici & 36 & 22.5 \\
\hline & Lezzetli+sağlıklı & 8 & 5.0 \\
\hline & Besleyici+alışkanlık & 9 & 5.6 \\
\hline & Lezzetli+besleyici+sağlıklı & 20 & 12.5 \\
\hline & Lezzetli+besleyici+alışkanlık+sağlıklı & 17 & 10.6 \\
\hline \multirow{6}{*}{ Et tüketim şekli } & Izgara & 6 & 3.8 \\
\hline & Haşlama & 19 & 11.9 \\
\hline & Fırında & 4 & 2.5 \\
\hline & Sebzeli & 4 & 2.5 \\
\hline & Yağda & 4 & 2.5 \\
\hline & Farketmez & 123 & 77.0 \\
\hline
\end{tabular}

$\aleph^{2}$ bağımsızlık testi sonucunda aylık kırmızı et tüketimi ile bazı demografik özellikler arasında istatistik olarak önemli seviyede bağımlılık bulunmuştur. Hanedeki birey sayısının aylık et tüketimi üzerine etkisi önemli bulunmuştur $(p<0.01)$. Buna göre, ailedeki birey sayısı 3-5 ve 5-8 kişi olduğu zaman aylık et tüketiminin daha fazla olduğu görülmektedir. Ailedeki birey sayısı 3 kişiden az olduğunda aylık et tüketim oranı daha az iken, 8 kişiden fazla olduğunda daha yüksek olarak bulunmuştur. $\mathrm{Bu}$ duruma hanelerin farklı aylık gelirlerinin etkisinin olduğu düşünülmektedir. Ailenin aylık geliri kırmızı et tüketim miktarını etkileyen önemli bir faktör olarak bulunmuştur $(p<0.05)$. Buna göre, aylık geliri 1400-3000 TL arasında olan kişilerin et tüketim miktarının daha yüksek olduğu anlaşılmaktadır. Daha sonra 3000 TL ve daha fazla geliri olan ailelerin et tüketim miktarı yüksek bulunmuştur. En az et tüketen ailelerin ise aylık gelirleri de en alt seviyede kalmaktadır. Ancak 1400- 
3000 TL geliri olanların 3000 TL ve daha fazla geliri olanlardan daha çok et tüketmesinin, kırmızı eti sevme ve sağlıklı bulma gibi çeşitli faktörlerden kaynaklandığı düşünülmektedir. Ailelerin aylık gıda harcamasına ayırdığı para miktarı ile et tüketim miktarı arasında önemli ilişki bulunmuştur $(p<0.01)$. Buna göre, en çok et tüketen ailelerin gıda harcamalarına ayırdıkları paylar sırasıyla 401-800 TL,
801-1500 TL, 400 TL ve daha az ve 1501 TL ve daha fazla şeklindedir. Burada da yine aylık gelir de olduğu gibi kırmızı eti sevme ve sağlıklı bulma gibi çeşitli faktörlerin et tüketim miktarına etkisi olmuştur (Çizelge 3). Yani et tüketim için aylık gelir önemli olmakla birlikte diğer faktörlerinde etkili olduğu anlaşılmıştır.

Çizelge 3. Kırmızı et tüketim miktarının bazı demografik özelliklere göre dağılımı

\begin{tabular}{|c|c|c|c|c|c|}
\hline \multirow{3}{*}{ Özellikler } & & \multicolumn{4}{|c|}{ Ayda ne kadar kırmızı et tüketiyorsunuz? } \\
\hline & & \multicolumn{2}{|c|}{5 kg'a kadar } & \multicolumn{2}{|c|}{5 kg ve daha fazla } \\
\hline & & $\mathbf{n}$ & $\%$ & $\mathbf{n}$ & $\%$ \\
\hline \multirow{4}{*}{ Hanede birey sayısı** } & 3 kişiden az & 25 & 21.4 & 3 & 6.8 \\
\hline & 3-5 kişi & 46 & 39.3 & 17 & 38.6 \\
\hline & 5-8 kişi & 41 & 35.0 & 16 & 36.4 \\
\hline & 8 kişiden fazla & 5 & 4.3 & 8 & 18.2 \\
\hline \multirow{3}{*}{ Ortalama aylık gelir* } & 1400 TL ve daha az & 24 & 20.9 & 2 & 4.7 \\
\hline & 1400-3000 TL arası & 61 & 53 & 23 & 53.5 \\
\hline & 3000 TL ve daha fazla & 30 & 26.1 & 18 & 41.9 \\
\hline \multirow{4}{*}{ Aylık ortalama gıda harcaması** } & 400 TL ve daha az & 16 & 13.7 & 1 & 2.3 \\
\hline & 401-800 TL arası & 77 & 65.8 & 20 & 45.5 \\
\hline & 801-1500 TL arası & 20 & 17.1 & 19 & 43.2 \\
\hline & 1501 TL ve daha fazla & 4 & 3.4 & 4 & 9.1 \\
\hline
\end{tabular}

$*: p<0.05, * *: p<0.01$ önem seviyesi

Yapılan $\aleph^{2}$ analizi sonuçlarına göre kırmızı et tüketim şekli tüketicilerin eğitim durumu, cinsiyeti, medeni hali ve yaşından bağımsız olduğu belirlenmiştir $(p>0.05)$. Kırmızı eti tercih etme nedenleri tüketicilerin cinsiyet ve medeni hal durumlarına göre önemli farklılık gösterirken $(p<0.01)$ yaş ve eğitim durumundan bağımsız bulunmuştur $(p>0.05)$. Erkek tüketiciler arasında en yüksek \%33.7'lik oran kırmızı eti lezzetli ve besleyici olduğu için tercih ederken, kadın tüketicilerde en yüksek \%19.5'lik kısım kırmızı eti sadece lezzetli buldukları için tercih ettiklerini bildirmişlerdir. İşlenmiş et ürünlerinin tüketilmesi durumu tüketicilerin medeni hal ve yaşlarına göre istatistiksel olarak önemli fark göstermezken, cinsiyet, eğitim durumu ve aylık ortalama gelir durumlarına göre önemli farklılıklar göstermiştir (Çizelge 4).

Çizelge 4. Tüketicilerin işlenmiş et ürünleri tüketme durumunun bazı özelliklere göre dağılımı (\%)

\begin{tabular}{ccccc}
\hline \multirow{2}{*}{ Özellikler } & & \multicolumn{3}{c}{ işlenmiş et ürünleri tüketme durumu } \\
\cline { 3 - 5 } & & Evet & Hayır & Toplam \\
\cline { 3 - 5 } Aylık Ortalama Gelir** (TL) & $\mathbf{1 4 0 0}$ TL ve daha az & 50.0 & 50.0 & 100 \\
& $\mathbf{1 4 0 0 - 3 0 0 0}$ TL arası & 77.4 & 22.6 & 100 \\
& $\mathbf{3 0 0 0}$ TL ve daha fazla & 85.4 & 14.6 & 100 \\
\hline \multirow{2}{*}{ Cinsiyet* } & Erkek & 83.3 & 16.7 & 100 \\
& Kadın & 67.5 & 32.5 & 100 \\
\hline \multirow{2}{*}{ Eğitim durumu* } & Okuryazar değil & 42.9 & 57.1 & 100 \\
& ilkokul & 66.7 & 33.3 & 100 \\
& Ortaokul & 65.4 & 34.6 & 100 \\
& Lise & 89.6 & 10.4 & 100 \\
\hline
\end{tabular}

$*: p<0.05, * *: p<0.01$ önem seviyesi. 
Tüketicilerin etin satın alınması şekli onların medeni hal ve cinsiyetlerine göre önemli farklılıklar göstermiştir (Çizelge 5). Bireylerin medeni durumu ve cinsiyeti et satın alma şekilleri üzerine etkili olmaktadır $(p<0.05, p<0.01)$. Evli insanlar eti satın alırken kemikli, kemiksiz veya kıyma oluşuna fazla dikkat etmediklerini belirtmişlerdir. Bu durumdan aile oldukları için tüm et şekillerini tüketebildikleri anlaşılmaktadır. Ancak bekâr insanlar ise sırasıyla kemikli, kemikli-kemiksiz ve kemiksiz eti daha çok tercih ettiklerini belirtmişlerdir. Bu durumun da bekâr insanların evden çok dışarda et tüketmesine ve Siirt ilinin meşhur büryan yemeğini daha çok tüketmelerine bağlı olarak değiştiği düşünülmektedir. Siirt ilinde erkekler ve kadınlar eti kemikli, kemiksiz veya kıyma şeklinde satın alırken, erkeklerin kemikli eti daha çok sevdiği kadınların ise kemiksiz eti daha çok sevdiği görülmektedir. Bu durumda insanın cinsiyet faktörü etkili olmuştur.

Mevcut çalışma ile elde edilen sonuçlar yapılan çalışmalarla bazı benzerlikler ve farklılıklar oluşturmaktadır. Bu benzerlikler ve farklılıkların bölgelerin sosyo-ekonomik durumlarından kaynaklı olduğu düşünülmektedir. Yaylak ve ark. (2010) araştırmasında ankete katılanların aylık gelirinin çoğunlukla 501-1500 TL arasında olduğunu bildirmiştir. Söz konusu araştırmada et tüketim şekli ve işlenmiş et ürünleri tüketimi konusundaki sonuçların bulgularımızla benzerlik gösterdiği anlaşılmıştır. Başka bir araştırmada ise (Karakaya ve Kızıloğlu, 2017) tüketicilerin ortalama aylık gelir ve gıda harcamalarının sırasıyla 3551.5 TL ve 876.8 TL olduğu ve aylık kırmızı et tüketim miktarının ise ortalama $4.40 \mathrm{~kg}$ olarak saptandığı araştırılmıştır. Aynı araştırmada katılımcıların \%88'i kırmızı et tükettiğini, \%48.9'u ise lezzetli olduğu için kırmızı et tükettiklerini ifade etmişlerdir. Akçay ve Vatansever (2013) Kocaeli ilinde yapmış olduğu çalışmada katılımcıların \%87.24'ünün kırmızı et tükettiğini, kırmızı etler içerisinde de en çok (\%89.55) dana etinin ızgara olarak tüketildiğini, tüketme nedeni olarak da besleyici olma özelliğinin ilk sırada yer aldığını ve yıllık kişi başına kırmızı et tüketiminin $10.46 \mathrm{~kg}$ olduğunu bildirmiştir. Aynı araştırmacı tüketicilerin aylık ortalama gelirini $1879.84 \mathrm{TL}$, aylık ortalama gıda harcamalarını ise 657.16 TL olarak bildirmiştir. Karakuş ve ark. (2008) Gaziantep ilinde kırmızı et tüketim alışkanlığını amaçladığı araştırmada ankete katılanların büyük bir çoğunluğu et tüketim şekli olarak ızgara ifadesini tercih ettiklerini belirtmişlerdir. Aynı araştırmada katılımcıların et alırken başta hijyen (\%35.4) ve etiketlenmesi (\%26.7) şartını birinci derecede önemli bulduklarını belirtmişlerdir. İkinci derecede ise etin tazeliği (\%32.3) ifadesine katılmışlardır. Karakuş ve ark. (2008) Gaziantep ilinde yapmış olduğu çalışmada et alım yeri özellikleri içerisinde tazeliğin ön planda olduğunu belirtmiştir. Yaylak ve ark. (2010) tüketicilerin et alırken ilk olarak güvenli ve taze olmasına dikkat ettiğini ifade etmiştir. Başka bir araştırmada da et satın alırken etin tazeliğinin öncelikli bir ölçüt olduğu bildirilmiştir (Şeker ve ark., 2011). Yine katılımcıların \%43.1'i orta fiyatlı, \%28.8'i ucuz fiyatlı ve \%26.9'u ise yüksek fiyatlı etleri tercih ettiklerini belirtmişlerdir. Yine katılımcıların et satın alma yeri durumu için \%64.4'ü kasap, \%18.1'i kasaplı marketi ve \%16.3'ü kasapsız marketi ilk sırada et satın alma olarak tercih ettiğini ifade etmiştir. Yaylak ve ark. (2010) çalışmasında tüketicilerin sırasıyla sığır (\%66.7), koyun (\%16.7) ve keçi (\%8.6) etini tercih ettiklerini tespit etmiştir. Aynı araştırmacı tüketicilerin eti kasaptan satın aldıklarını belirtmiştir. Karakaya ve Kızıloğlu (2017) tüketicilerin kasaptan çoğunlukla koyun etini kıyma şeklinde aldığını ve alırken de tazelik ve kaliteye baktıklarını belirtmiştir. Şeker ve ark. (2011) Elazığ ilinde yapmış olduğu çalışmada tüketicilerin \%55.3'ünün dana etini tercih ettiğini ve et satın alırken kasabı (\%66.3) tercih ettiklerini bildirmiştir.

Çizelge 5. Tüketicilerin etin satın alınma şeklinin bazı demografik özelliklere göre dağılımı (\%)

\begin{tabular}{|c|c|c|c|c|c|c|c|c|c|}
\hline & \multicolumn{9}{|c|}{ Etin satın alınma şekli } \\
\hline \multicolumn{2}{|c|}{ Özellikler } & Kemiksiz & Kıуma & Kemikli & $\begin{array}{l}\text { Kemiksiz } \\
\text { ve kıyma }\end{array}$ & $\begin{array}{c}\text { Kemikli ve } \\
\text { kemiksiz }\end{array}$ & $\begin{array}{c}\text { Kemikli } \\
\text { ve kıyma }\end{array}$ & $\begin{array}{c}\text { Fark } \\
\text { etmez }\end{array}$ & Toplam \\
\hline \multirow{3}{*}{$\begin{array}{l}\text { Medeni } \\
\text { hal* }\end{array}$} & Evli & 17.2 & 7.8 & 14.8 & 5.5 & 5.5 & 3.9 & 45.3 & 100 \\
\hline & Bekâr & 11.5 & 7.7 & 34.6 & 11.5 & 15.4 & 7.7 & 11.5 & 100 \\
\hline & Dul & 20 & 0 & 0 & 0 & 0 & 0 & 80 & 100 \\
\hline \multirow{2}{*}{ Cinsiyet** } & Erkek & 16.9 & 10.8 & 25.3 & 4.8 & 10.8 & 6.0 & 25.3 & 100 \\
\hline & Kadın & 15.6 & 3.9 & 9.1 & 9.1 & 2.6 & 2.6 & 57.1 & 100 \\
\hline
\end{tabular}

$*: p<0.05, * *: p<0.01$ önem seviyesi. 


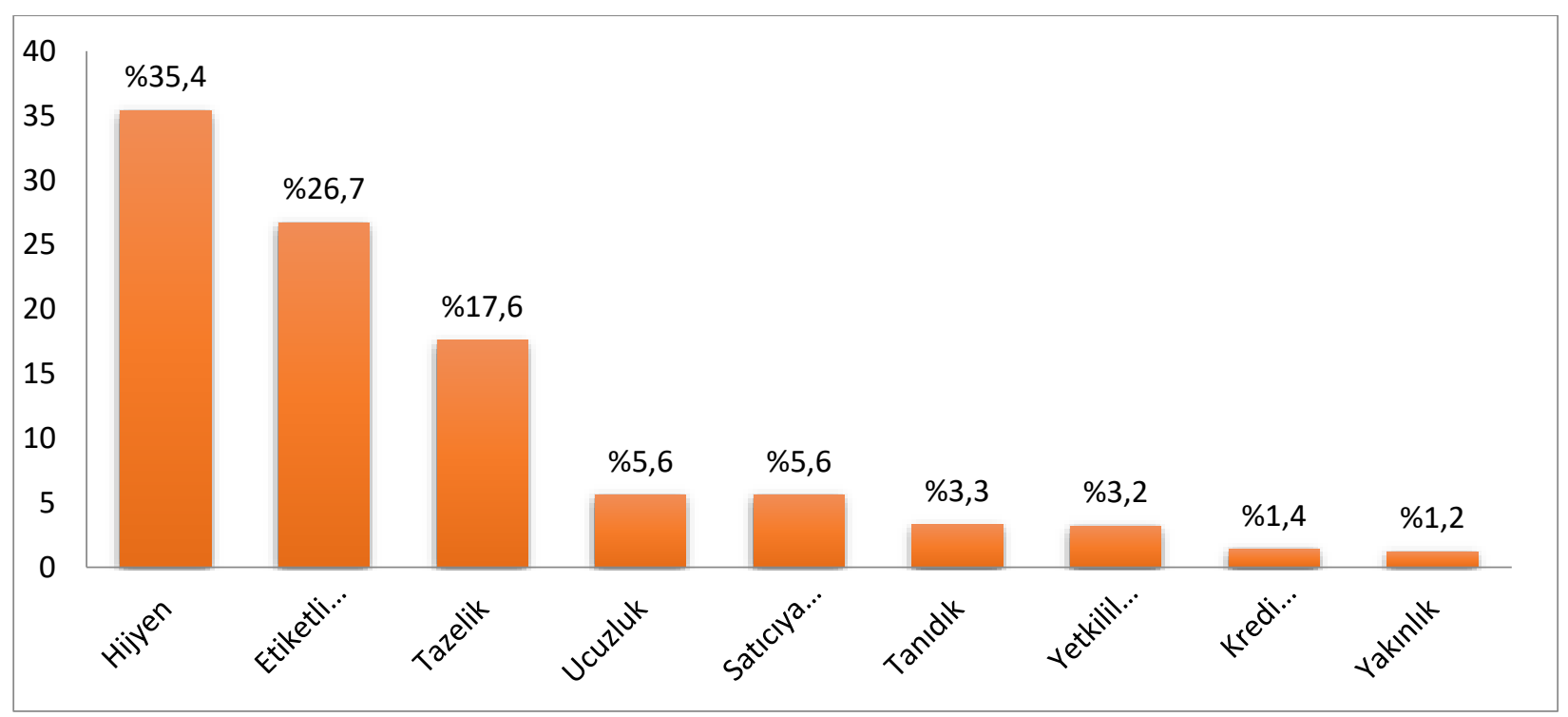

Şekil 2. Anket sahiplerinin et satın alma yerinin seçiminde tercihleri.

\section{Sonuç ve Öneriler}

Sonuç olarak Siirt il merkezinde çoğunlukla koyun etinin tüketildiği, bunu keçi ve dana etinin izlediği görülmektedir. Katılımcıların et alım yeri seçerken etin hijyenik olmasını, etiketli olmasını ve taze olmasını dikkate aldıkları saptanmıştır. Siirt il merkezinde et tüketim sebebinin etin lezzetli ve besleyici olmasından kaynaklandığı ve dolayısıyla tüketicilerin fiyattan ziyade etin taze olmasına ve hijyenik olmasına dikkat ettiği görülmektedir. Siirt ilinde küçükbaş faaliyetlerinin yoğun olması sebebiyle koyun ve keçi etinin daha çok tüketildiği düşünülmektedir.

Türkiye'de kişi başına yıllık et tüketimi oldukça düşüktür. Günümüze kadar hem nüfusta hem de kişi başına et tüketiminde sırasıyla meydana artışlar değerlendirildiğinde, büyükbaş ve küçükbaş hayvan sayısında meydana gelen artışın nüfus ve et tüketiminin gerisinde kaldığı anlaşılmaktadır. Dolayısıyla önemli hayvansal ürünlerden kırmızı etin tüketiminin sağlanması, buna ilişkin tüketici davranışlarının belirlenmesi, bu davranışlar bakımından gözlenen farklılıkların analiz edilmesi, bu ürünlerin üretiminde hayvandan sofraya kadar olan süreçte etkili denetim mekanizmalarının oluşturulması, sürdürülebilir bir kalite standardının geliştirilmesi kaçınılmaz görünmektedir. Çok önemli bir konu da bu ürünlerin üretiminde temel kaynak niteliğinde olan hayvancılı̆ımızın genel sorunları bağlamında çözümler üretilebilmesi, gelecekte öngörülebilir ihtiyaçlarımızın belirlenmesi ve üretimin bu yönde yönlendirilmesi yapılması gereken önemli işlerden sadece bir kaçı olarak ortaya çıkmaktadır.

\section{Kaynaklar}

Akçay, Y., Vatansever, Ö. 2013. Kırmızı et tüketimi üzerine bir araştırma: Kocaeli ili kentsel alan örneği. Journal of Institute of Social Sciences, 4(1): 43-60.

Arısoy, H., Bayramoğlu, Z. 2014. Consumers' determination of red meat and meat products purchase behaviour - city of Ankara sample. Turkish Journal of Agriculture-Food Science and Technology, 31: 28-34.

Arıtaşı, C. 2009. Et ve Balık İşleme Teknolojisi Ders Notları. Namık Kemal Üniversitesi, Tekirdağ.

Font-i-Furnols, M., Guerrero, L. 2014. Consumer preference, behavior and perception about meat and meat products: An overview. Meat science, 98(3): 361-371.

Göğüş, A.K. 1986. Et Teknolojisi. Ankara Üniv. Zir. Fak. Yayınları: 991, Ders Kitabı: 291.

Kan, A., Direk, M. 2004. Course of red meat prices in the Konya province. Selçuk Üniversitesi Ziraat Fakültesi Dergisi, 18: 35-40.

Karakaya, E., Kızıloğlu, S. 2017. Bingöl i̇ merkezinde yaşayan hane halklarının kırmızı et talebini etkileyen faktörlerin analizi. Anadolu Tarım Bilimleri Dergisi, 32(2): 169-180.

Karakuş, K. Aygün, T., Alarslan, E. 2008. Gaziantep ili merkez ilçede kırmızı et tüketim alışkanlıkları. Yüzüncü Yıl Üniversitesi Tarım Bilimleri Dergisi, 18(2): 113-120.

Kibar, M., Mikail, N. 2018. Application of conjoint analysis to determine consumers 'red meat preferences in Siirt province. Scientific Papers: 
Series D, Animal Science-The International Session of Scientific Communications of the Faculty of Animal Science, $61 \mathrm{p}$.

Newbold, P. 1995. Statistics for Business and Economics. Prentice-Hall International, New Jersey, $867 \mathrm{p}$.

Onurlubaş, E., Yılmaz, N., Doğan, H.G., Kızılaslan, H. 2015. A research on red meat consumption and preferences: a casestudy in Tekirdağ Province. Turkish Journal of AgricultureFoodScience and Technology, 3(6): 466-471.

Rimal, A.P. 2002. Factors affecting meat preferences among American consumers. Family Economics and Nutrition Review, 14(2): 36-44.

Şeker, İ. Özen, A. Güler, H. Şeker, P., Özden, İ. 2011. Elazığ'da kırmızı et tüketim alışkanlıkları ve tüketicilerin hayvan refahı konusundaki görüşleri. Kafkas Univ. Vet. Fak. Derg., 17(4): 543-550.

Tömek, S. 1989. Et Teknolojisine Giriş. Ege Üniv. Müh. Fak. Çoğaltma Yayın, 65, 38.

Turan, N. Özyazıcı, M.A. ve Tantekin, G.Y, 2015. Siirt ilinde çayır mera alanlarından ve yem bitkilerinden elde edilen kaba yem üretim potansiyeli. Türkiye Tarımsal Araştırmalar Dergisi, 2 (1): 69-75.

TÜiK, 2018a. (https://biruni.tuik.gov.tr) (Erişim tarihi: 18.06.2019).

TÜiK, 2018b. (https://biruni.tuik.gov.tr) (Erişim tarihi:18.06.2019).

Yaylak, E., Taşkın, T., Koyubenbe, N., Konca, Y. 2010. İzmir ili Ödemiş ilçesinde kırmızı et tüketim davranışlarının belirlenmesi üzerine bir araştırma. Hayvansal Üretim, 51(1).

Yücel, A. 2001. Et ve Su Ürünleri Teknolojisi. IV. Baskı. Uludağ Üniv. Zir. Fak. Ders Notları No: 47. 